\title{
25th Anniversary of the Geneva Association
}

\author{
by Sir Brian Corby*
}

I have always been of the view that the major role of the Geneva Association is to bring about a greater understanding of the function and importance of the insurance industry in the economy on the part of Governments, academia and policy formers generally. We would thereby enhance the standing of the industry and bring about an improvement in the conditions under which it operates. Whilst we have not perhaps achieved all we might have hoped, I believe that the past 25 years has been a period of general success for the Association when measured against its objectives.

That this is so says much for the foresight of the founding members, the continuity and commitment of the membership as a whole and the ability and vision of Orio Giarini, our original, and current, Secretary General.

My four years as President included the 20th anniversary of the Society. More importantly, it included a review of the role of the Association under the Chairmanship of my successor as President, Jan Holsboer. The result of this review - referred to as a "refounding" in the report on our activities for 1994/95 - essentially confirmed our original objectives as still relevant whilst applying a tighter focus on our activities.

The review was occasioned by a number of factors but I draw attention to two. The first was related to the then problems of profitability in the industry, which inevitably led to a shorter term view being taken by industry leaders and a questioning of the relevance of the longer term approach, which was, and is, the hallmark of the Association. The second was the developing EU legislation and the need to differentiate clearly between the work of the Association on the one hand - which by then, of course, stretched beyond Europe - and the various national and European insurance associations, particularly the CEA.

* President of the Geneva Association from 1990-1994. 
I have just referred to the continuity of membership; what is also notable is the continuity of themes pursued by the Association. I mention just a few of these.

The first is the importance and relevance to the modem economy of the proper understanding of risk and how society can both cope with risk and manage it. The role that insurance plays in this is clear, as is a proper understanding of the concept of insurability.

The second is to recognise the convergence that is taking place between what has historically been regarded as the manufacturing sector of the economy and the service sector, of which insurance is a significant part. The Uruguay round of GATT had as its objective the liberalization of services and the Association took a major role in the various conferences in Geneva. It also led the meeting on financial services when introduced into the World Economic Forum in Davos.

Finally, to mention the work on social security in general - the annual lecture in 1991, for example, was on the subject of "The future of social insurance" - and the work on the Four Pillars in particular. The Association began the latter work well ahead of Governments being prepared to acknowledge that there were issues to be addressed, and has contributed to the debates which are increasingly taking place throughout the world. It is only through this kind of research and debate that public acceptability of actions which have to be taken, even if painful, can be obtained.

Whilst the Association remains primarily based on Europe, its membership includes senior executives from major insurance companies across the world. This is indicative of the standing which the Association has achieved over its first 25 years, and also the global nature of the issues which it addresses. I look forward to the next 25 years. 